\title{
Akdeniz ve Ege Bölgelerine ait bazı arpa (Hordeumvulgare l.) köy çeşitlerinin bitki besin elementi içeriklerinin karşılaştırılması
}

\section{Comparison of plant nutrient content of some barley landraces (Hordeum vulgare l.) of Mediterranean and Aegean Regions}

\author{
Erbil DEMİR, Sahriye SÖNMEZ(i) \\ Akdeniz Üniversitesi, Ziraat Fakültesi, Toprak Bilimi ve Bitki Besleme Bölümü, 07070, Antalya \\ Sorumlu yazar (Corresponding author): E. Demir, e-posta (e-mail): erbil.demir07@gmail.com \\ Yazar(lar) e-posta (Author e-mail): ssönmez@akdeniz.edu.tr
}

MAKALE BILGISII

Alınıs tarihi 12 Mart 2019

Düzeltilme tarihi 19 Nisan 2019

Kabul tarihi 26 Nisan 2019

\section{Anahtar Kelimeler:}

Arpa

Çeşit

Element

Makro

Mikro

\section{$\ddot{O Z Z}$}

Bu çalışma; Akdeniz ve Ege Bölgelerine ait 26 adet yerel arpa çeşidi ile Türkiye'de yetiștirilen 2 adet tescilli arpa çeșidinin makro-mikro bitki besin elementi içerikleri ile protein oranlarının belirlenmesi ve arpa çeşitleri arasındaki farklılıkları ortaya koymak amacıyla yapılmıştır. Her bir çeşitten alınan yaprak ve dane örneklerinde makro - mikro element içerikleri belirlenmiștir. Ayrıca dane örneklerinin ham protein içeriği de belirlenmiștir. Yapılan istatistiki analizler sonucunda yerel arpa çeşitlerinin yaprak ve dane örneklerinin makro - mikro element icerikleri ile dane örneklerinin protein içeriklerinin istatistiki anlamda önemli farklılıklar içerdiği belirlenmiştir. Yerel arpa çeşitlerinin yaprak örneklerinin toplam azot $(\mathrm{N})$ içeriklerinin \%2.02-3.78, fosfor $(\mathrm{P})$ içeriklerinin \%0.19-0.35, potasyum $(\mathrm{K})$ içeriklerinin \%0.81-2.40, kalsiyum $(\mathrm{Ca})$ içeriklerinin \%0.9-1.7, magnezyum $(\mathrm{Mg})$ içeriklerinin \%0.17-0.36 arasında değişim gösterdiği belirlenmiştir. Yerel arpa çeşitlerinin yaprak örneklerinin demir $(\mathrm{Fe})$ içeriklerinin 70.5-192.9 ppm, mangan $(\mathrm{Mn})$ içeriklerinin 35.5-169.5 ppm, bakır $(\mathrm{Cu})$ içeriklerinin 4.3-26.9 ppm ve çinko $(\mathrm{Zn})$ içeriklerinin 6.0-21.8 ppm arasında değişim gösterdiği belirlenmiştir. Yapılan dane analizleri sonucunda çeşitlerin toplam $\mathrm{N}$ içerikleri \%1.65-2.54, protein içerikleri \%9.6-14.8, P içerikleri 3476-5993 ppm, K içerikleri $1156-6319$ ppm, Ca içerikleri 725-1616 ppm ve Mg içerikleri bakımından ise 1368-2261 ppm arasında değișim gösterdiği belirlenmiștir. Mikro element içerikleri bakımından ise çeșitlerin Fe içerikleri 22.7-75.1 ppm, Mn içerikleri 12.0-22.1 ppm, $\mathrm{Zn}$ içerikleri 16.9-43.3 ppm ve $\mathrm{Cu}$ içerikleri bakımından ise 2.2-4.4 ppm arasında değișim gösterdiği belirlenmiştir.

\section{ARTICLE INFO}

Received 12 March 2019

Received in revised form 19 April 2019 Accepted 26 April 2019

Keywords:

Barley

Variety

Element

Macro

Micro

\begin{abstract}
This study was conducted to demonstrate the differences between the macro-micro plant nutrient content with the determination of protein content and barley varieties have 2 registered barley varieties grown in Turkey with 26 pieces of local barley varieties belonging to the Mediterranean and Aegean. Macro-micro element contents were determined in each leaf and grain samples. The crude protein content of the grain samples was also determined. As a result of the statistical analysis, it was determined that the macro-micro element contents of the leaf and grain samples of the local barley varieties and the protein contents of the grain samples contained statistically significant differences. It was determined that the total $\mathrm{N}$ content of the leaf samples of local barley varieties varied between $2.02-3.78 \%$, the $\mathrm{P}$ contents of $0.19-0.35 \%$, the $\mathrm{K}$ contents of $0.81-2.40 \%$, the Ca content of $0.9-1.7 \%$, the $\mathrm{Mg}$ contents of $0.17-0.36 \%$. It was determined that the Fe content of the leaf samples of the local barley varieties ranged from 70.5-192.9 ppm, the Mn contents ranged from 35.5-169.5 ppm, the Cu contents ranged from 4.3-26.9 ppm and the zinc contents ranged from 6.0-21.8 ppm. As a result of grain analysis, it has been identified that the total $\mathrm{N}$ content of the varieties ranged from $1.65-2.54 \%$, protein content was $9.6-14.8 \%$, the $\mathrm{P}$ content was $3476-5993 \mathrm{ppm}$, the $\mathrm{P}$ content was 1156-6319 ppm, the Ca content was 725-1616 ppm and $\mathrm{Mg}$ contents was 1368 $2261 \mathrm{ppm}$. In terms of micro element contents, the Fe content of the varieties ranged from 22.7-75.1 ppm, Mn content ranged from 12.0-22.1 ppm, Zn contents ranged from 16.9-43.3 ppm and $\mathrm{Cu}$ contents ranged from 2.2-4.4 ppm.
\end{abstract}




\section{Giriş}

İnsan sağlığının ve hayvan beslenmesinin daha da ön plana çıktığı günümüz koşullarında, besin değeri yüksek ürünlere olan ilgi giderek artış göstermektedir. Özellikle son yıllarda yem bitkilerine olan ihtiyacın giderek artması ve hayvancılık faaliyetlerinin giderek azalması önemli bir yem ve ayn zamanda önemli bir tahıl olan arpa bitkisine olan çalışmalara ihtiyacı da artırmaktadır. Arpa, içermiş olduğu bitki besin elementleri ve vitaminlerin yanı sıra özellikle protein içeriği yönünden oldukça önemli bir yem bitkisidir.

Hayvan beslemede çok büyük bir öneme sahip olmasına rağmen, ülkemizde yem bitkileri yetiştiriciliğine gereken önem verilmemiştir. Tarımı ilerlemiş ülkelerde tarımsal alanlar içinde yem bitkileri ekim alanlarının oranı yaklaşık olarak \%25 iken ülkemizde bu oran \%3.1'i geçmemektedir (Açıkgöz ve ark. 2005; Elçi 2005).

Türkiye arpa çeşitliliği bakımından önemli ülkeler arasında yer almaktadır. Literatür taramaları incelendiğinde, önemli bir yem bitkisi olan ve aynı zamanda insan beslenmesinde değişik şekillerde yararlanılan arpa bitkisi ile ilgili çalışmaların daha çok kalite kriterleri açısından değerlendirildiği, arpanın mineral bileşimleri ile ilgili yapılan çalışmaların ise daha az olduğu dikkat çekmektedir. Yürütülen bu çalışma ile ICARDA (International Center for Agricultural Research in the Dry Areas)'dan temin edilen Türkiye'nin Akdeniz ve Ege Bölgelerine ait 26 adet yerel arpa çeşitleri ile Türkiye'de yetiştirilen 2 adet tescilli arpa çeşidin (Bülbül 89 ve Akhisar 98) makro ve mikro bitki besin elementlerinin düzeylerinin belirlenmesi, bu arpa çeşitlerinin protein oranlarının miktarlarının tespit edilmesi amaçlanmıştır. Arpa köy çeşitlerinin bitki besin elementi içerikleri karşılaştırılarak, mineral beslenme bakımından incelenmiş ve aralarında kalite 1slahında kullanılabilecek önemli farklılıkların olup olmadığı araştırılmıştır.

\section{Materyal ve Yöntem}

$\mathrm{Bu}$ araştırma 2015-2016 vejetasyon döneminde Akdeniz Üniversitesi Ziraat Fakültesi Uygulama Çiftliği arazisinde tarla denemesi şeklinde yağışa bağlı koşullar altında kışlık olarak yürütülmüştür. Deneme materyali olarak ICARDA (International Center for Agricultural Research in the Dry Areas)'dan temin edilen Türkiye'nin Akdeniz ve Ege Bölgelerine ait 26 adet yerel arpa çeşidi ile Türkiye'de yaygın bir şekilde yetiştirilen Akhisar 98 ve Bülbül 89 olan tescilli çeşitler kontrol amacıyla kullanılmıştır (Çizelge 1).

Deneme kurulmadan önce deneme alanının toprak özelliklerini belirlemek amaciyla toprak örnekleri, Jackson (1967) tarafından bildirilen esaslara uygun olarak alınmıştır. Toprak örnekleri Chapman ve ark. (1961) bildirdiği esaslara uygun olarak analize hazır hale getirilmiştir. Toprak örneklerinin bünyesi Bouyoucos (1955) tarafindan bildirilen esaslara göre hidrometre yöntemiyle, toprak reaksiyonu $(\mathrm{pH})$ ve elektriksel iletkenlik (EC) 1:2.5 toprak-su karışımında (Jackson 1967), kireç $\left(\mathrm{CaCO}_{3}\right)$ Scheibler Kalsimetresi ile (Çağlar 1949), organik madde (\%) Modifiye Walkley-Black metoduna göre (Black 1965), toplam N Modifiye Kjeldahl metoduna göre (Kacar ve İnal 2008), alınabilir P Olsen metoduna göre (Olsen ve Sommers 1982), değişebilir $\mathrm{K}, \mathrm{Ca}, \mathrm{Mg}, \mathrm{Na} 1 \mathrm{~N}$ Amonyum Asetat (pH: 7) metoduna göre;alınabilir $\mathrm{Fe}, \mathrm{Mn}, \mathrm{Zn}$ ve $\mathrm{Cu}$ DTPA ekstraksiyonu (Lindsay ve Norvell 1978) yolu ile belirlenmiş ve analiz sonuçları Çizelge 2'de verilmiştir.

Çizelge 1. Araştırmada kullanılan yerel arpa çeşitleri.

Table 1. Local barley varieties used in research.

\begin{tabular}{cccc}
\hline Sıra No & Yerel Çeşitler & İl & Bölge \\
\hline $\mathbf{1}$ & IG 18801 & Denizli & Ege \\
$\mathbf{2}$ & IG 18842 & Aydın & Ege \\
$\mathbf{3}$ & IG 19097 & Manisa & Ege \\
$\mathbf{4}$ & IG 19110 & Muğla & Ege \\
$\mathbf{5}$ & IG 28579 & Muğla & Ege \\
$\mathbf{6}$ & IG 28582 & Muğla & Ege \\
$\mathbf{7}$ & IG 28588 & Manisa & Ege \\
$\mathbf{8}$ & IG 28596 & Manisa & Ege \\
$\mathbf{9}$ & IG 28715 & Denizli & Ege \\
$\mathbf{1 0}$ & IG 128075 & Kahramanmaraş & Ege \\
$\mathbf{1 1}$ & IG 128078 & Uşak & Ege \\
$\mathbf{1 2}$ & G 128079 & Afyonkarahisar & Ege \\
$\mathbf{1 3}$ & IG 128080 & Kütahya & Ege \\
$\mathbf{1 4}$ & IG 128081 & Kütahya & Ege \\
$\mathbf{1 5}$ & IG 128083 & Kütahya & Akdeniz \\
$\mathbf{1 6}$ & IG 128111 & Adana & Akdeniz \\
$\mathbf{1 7}$ & IG 128113 & Gaziantep & Akdeniz \\
$\mathbf{1 8}$ & IG 128116 & Isparta & Akdeniz \\
$\mathbf{1 9}$ & IG 128120 & Burdur & Akdeniz \\
$\mathbf{2 0}$ & IG 128134 & Hatay & Akdeniz \\
$\mathbf{2 1}$ & IG 128135 & Mersin & Akdeniz \\
$\mathbf{2 2}$ & IG 128136 & Antalya & Ege \\
$\mathbf{2 3}$ & IG 128166 & İzmir & Ege \\
$\mathbf{2 4}$ & IG 128180 & İzmir & Akdeniz \\
$\mathbf{2 5}$ & IG 128190 & Mersin & Ege \\
$\mathbf{2 6}$ & IG 128192 & İzmir & \\
\hline
\end{tabular}


Çizelge 2. Deneme alanı toprağının fiziksel ve kimyasal özellikleri. Table 2. Physical and chemical properties of the trial area.

\begin{tabular}{|c|c|}
\hline Toprak Özelliği & Sinıf \\
\hline Bünye & Killi Tın \\
\hline $\mathrm{pH}$ & Nötr \\
\hline $\mathrm{EC}(\mathrm{ds} / \mathrm{m})$ & Tuzsuz \\
\hline Organik Madde (\%) & Orta \\
\hline Kireç $\left(\% \mathrm{CaCO}_{3}\right)$ & Çok Yüksek \\
\hline Toplam N (\%) & Düșük \\
\hline Alınabilir P (ppm) & Orta \\
\hline Değişebilir K (ppm) & Düşük \\
\hline Değişebilir Mg (ppm) & Orta \\
\hline Değişebilir Ca (ppm) & Yüksek \\
\hline Değişebilir Na (ppm) & Düşük \\
\hline Alınabilir Fe(ppm) & Yeterli \\
\hline Alınabilir Zn(ppm) & Yeterli \\
\hline Alınabilir $\mathrm{Cu}$ (ppm) & Yeterli \\
\hline Alınabilir Mn (ppm) & Yeterli \\
\hline
\end{tabular}

Araştırma Akdeniz Üniversitesi Ziraat Fakültesi Uygulama Çiftliği deneme alanında Tesadüf Blokları Deneme Desenine göre 3 tekerrürlü olarak yürütülmüştür. Bitkiler $20 \mathrm{~cm}$ sıra aralığı, $3 \mathrm{~m}$ sıra boyu, 5 sıra halinde ekilmiş ve ekim miktarı 20 $\mathrm{kg} \mathrm{da}{ }^{-1}$ olarak ayarlanmıştır. Ekim 28 Kasım 2015 tarihinde yapılmıştır. Parsellere çiftçi koşulları esas alınarak triplesüperfosfat ve amonyum nitrat halinde dekara $7.5 \mathrm{~kg} \mathrm{P}_{2} \mathrm{O}_{5}$ ve $8 \mathrm{~kg} \mathrm{~N}$ hesabıyla gübre uygulaması yapılmıştır (Kandemir 2004). Fosforlu gübrenin tamamı ve azotlu gübrenin yarısı ekimle birlikte, azotlu gübrenin diğer yarısı sapa kalkma dönemi öncesi verilmiştir. Bitkilerin hasadı danedeki nem oranı \%12-13'ün altına düştüğünde elle yapılmıştır.

Yaprak örneklemesi, genotiplerin başaklanma döneminde 26-30 Nisan 2016 tarihleri arasında; dane örneklemesi ise 30-31 Mayıs 2016 tarihleri arasında, danedeki nem oranı \%12-13 ün altına indiğinde yapılmıştır. Her bitkiden alınan yaprak ve dane örnekleri delikli torbalara konulmuş ve en kısa sürede laboratuvara getirilmiştir. Çalışma kapsamında yetiştirilen her çeşit için alınan yaprak örnekleri kontaminasyona karşı önce musluk suyundan daha sonra ise 2 defa saf sudan geçirilmiştir. Yaprak ve dane örnekleri $65^{\circ} \mathrm{C}^{\prime}$ ye ayarlı kurutma dolabında son tartım sabit kalıncaya kadar kurutulmuş ve bitki öğütme değirmeninde öğütülerek analize hazır hale getirilmiştir (Kacar ve İnal 2008).

Yaprak ve dane örneklerinde toplam N; Modifiye Kjeldahl metoduna göre (Kacar ve İnal 2008), P, K, Ca, Mg, Fe, Mn, Zn, ve $\mathrm{Cu}$ içerikleri Kacar ve İnal (2008)'ın bildirdiği şekilde yaş yakılması metodu ile elde edilen süzükte ICP-OES (Inductively Coupled Plasma) kullanılarak belirlenmiştir. Arpa dane örneklerinin ham protein içeriği ise; danelerin toplam $\mathrm{N}$ içeriği ile arpanın protein katsayı değeri olan 5.83 ile çarpılması sonucu hesaplanmıştır (Kacar ve İnal 2008).

Elde edilen sonuçlar varyans analizlerine tabi tutulup, sonuçlar MINITAB 17 istatistiksel analiz programı kullanılarak Tukey testine göre karşılaştırılmıştır. Yaprak örneklerinin analiz sonuçları Jones ve ark. (1991) tarafindan verilen optimum sınır değerleri ile karşılaştırılmıştır.

\section{Bulgular ve tartışma}

3.1. Yaprak örneklerinin makro ( $N, P, K, C a$ ve $M g$ ) ve mikro ( $F e, M n, Z n$ ve $\mathrm{Cu}$ ) element analiz sonuçları

Toplam N içerikleri bakımından yerel arpa çeşitlerinin yaprak örnekleri değerlendirildiğinde en yüksek toplam $\mathrm{N}$ içeriği \%3.78 ile IG 128078 numaralı çeşitte belirlenirken, en düşük toplam N içeriği \%2.02ile IG 128192 numaralı çeşitte belirlenmiştir. Bülbül-89 referans çeşidi \%3.12 toplam N içeriği ile yerel arpa çeşitlerinin bazılarından yüksek, bazılarından ise düşük toplam $\mathrm{N}$ içeriğine sahip olduğu belirlenmiştir. Akhisar98 referans çeşidi ise \%2.58 toplam N içeriği ile IG 128081, IG 128190 ve IG 128192 çeşitleri hariç diğer yerel çeşitlerin hepsinden daha düşük toplam $\mathrm{N}$ içerdiği belirlenmiştir (Çizelge 3). Yaprak örneklerinin analiz sonuçları Jones ve ark. (1991) tarafından yeterli olarak belirlenen \%1.75-3.00 sınır değerleri ile karşılaştırıldığında \%71.4'ünün yeterli ve \%28.6'sının ise yüksek düzeyde toplam $\mathrm{N}$ içerdiği belirlenmiştir.

Fosfor içerikleri bakımından yerel arpa çeşitlerinin yaprak örnekleri değerlendirildiğinde; en yüksek P içeriği \%0.35 ile IG 128136 numaralı çeşitte saptanırken, en düşük P içeriği IG 18842 numaralı çeşitte $\% 0.19$ olarak belirlenmiştir. Bülbül-89 $(\% 0.19)$ ve Akhisar-98 (\%0.13) referans çeşitlerinin ise yerel arpa çeşitlerine göre daha düşük $\mathrm{P}$ içeriğine sahip olduğu tespit edilmiştir (Çizelge 3). Yaprak örneklerinin P analiz sonuçları Jones ve ark. (1991) tarafindan yeterli olarak belirlenen \%0.200.50 sınır değerleri ile karşılaştırıldığında \%10.7'sinin noksan ve \%89.3'ünün ise yeterli düzeyde $\mathrm{P}$ içerdiği belirlenmiştir.

Potasyum içerikleri bakımından yerel arpa çeşitlerinin yaprak örnekleri değerlendirildiğinde; en yüksek $\mathrm{K}$ içeriğ $\% 2.40$ ile IG 128083 numaralı çeşitte; en düşük $\mathrm{K}$ içeriği ise $\% 0.81$ ile IG 18801 numaralı çeşitte belirlenmiştir. Bülbül-89 (\%0.91) ve Akhisar-98 (\%0.45) referans çeşitlerinin; yerel arpa çeşitlerinden daha düşük $\mathrm{K}$ içeriğine sahip olduğu tespit edilmiştir (Çizelge 3). Yaprak örneklerinin $\mathrm{K}$ analiz sonuçları Jones ve ark. (1991) tarafindan yeterli olarak belirlenen \%1.503.00 sınır değerleri ile karşılaştırıldığında \%46.4'ünün noksan ve \%53.6'sının ise yeterli düzeyde $\mathrm{K}$ içerdiği belirlenmiştir.

Kalsiyum içerikleri bakımından yerel arpa çeşitlerinin yaprak örnekleri değerlendirildiğinde en yüksek $\mathrm{Ca}$ içeriği $\% 1.78$ ile IG 128120 ve IG 128192 numaralı çeşitlerde, en düşük Ca içeriği \%0.9 ile IG 128083 ve IG 128116 numaralı çeşitlerde belirlenmiştir. Referans çeşitleri Bülbül-89 (\%1.0) yerel çeşitlere göre daha düşük Ca içerirken, Akhisar-98 (\%1.6) çeşidi ise yerel arpa çeşitlerine göre daha yüksek $\mathrm{Ca}$ içeriğine sahip olmuştur (Çizelge 3). Yaprak örneklerinin $\mathrm{Ca}$ analiz sonuçları Jones ve ark. (1991) tarafindan yeterli olarak belirlenen \%0.30-1.20 sınır değerleri ile karşılaştırıldığında \%53.6'ünün yeterli ve \%46.4'ünün yüksek düzeyde Ca içerdiği belirlenmiştir.

Magnezyum içerikleri bakımından yerel arpa çeşitlerinin yaprak örnekleri değerlendirildiğinde en yüksek $\mathrm{Mg}$ içeriği $\% 0.36$ ile IG 128078 numaralı çeşitte, en düşük $\mathrm{Mg}$ içeriğ $\% 0.17$ ile IG 128180 numaralı çeşitte belirlenmiştir. Referans çeşitleri \%0.25 Mg içerikleri ile yerel arpa çeşitlerinin çoğuna göre daha düşük Mg içeriğine sahip olmuşlardır (Çizelge 3). Yaprak örneklerinin analiz sonuçları Jones ve ark. (1991) tarafindan yeterli olarak belirlenen \%0.15-0.50 sinır değerleri ile karşılaştırıldığında \%100'ünün yeterli düzeyde $\mathrm{Mg}$ içerdiği belirlenmiştir.

Demir içerikleri bakımından yerel arpa çeşitlerinin yaprak örnekleri değerlendirildiğinde en yüksek Fe içeriği 192.9 ppm ile IG 128136 numaralı çeşitte, en düşük Fe içeriği ise 70.5 ppm ile IG 128120 numaralı çeşitte belirlenmiştir. Bülbül-89 (89.5 ppm) ve Akhisar-98 (97.8 ppm) çeşitleri yerel arpa çeşitlerine yakın Fe içeriğine sahip olmuşlardır (Çizelge 4). Yaprak örneklerinin analiz sonuçları Plank ve Donohue (2000) tarafından yeterli olarak belirlenen 30-200 ppm sınır değerleri 
Çizelge 3. Yaprak örneklerinin makro besin elementi içerikleri.

Table 3. Macro nutrient content of leaf samples.

\begin{tabular}{|c|c|c|c|c|c|c|}
\hline Sira No & Çeşitler & N\% & P \% & K \% & Ca \% & Mg \% \\
\hline 1 & Bülbül 89 & $3.12 \mathrm{~A}-\mathrm{F}$ & $0.19 \mathrm{O}$ & $0.91 \mathrm{I}$ & $1.0 \mathrm{~L}-\mathrm{M}$ & $0.25 \mathrm{G}-\mathrm{K}$ \\
\hline 2 & Akhisar98 & $2.58 \mathrm{E}-\mathrm{G}$ & $0.13 \mathrm{P}$ & $0.45 \mathrm{~J}$ & $1.6 \mathrm{~A}-\mathrm{C}$ & $0.25 \mathrm{H}-\mathrm{K}$ \\
\hline 3 & IG 128075 & $2.87 \mathrm{D}-\mathrm{F}$ & $0.29 \mathrm{D}-\mathrm{G}$ & $1.64 \mathrm{E}$ & 1.4 E-H & $0.23 \mathrm{~J}-\mathrm{K}$ \\
\hline 4 & IG 128111 & $2.86 \mathrm{D}-\mathrm{F}$ & $0.26 \mathrm{~F}-\mathrm{L}$ & $2.04 \mathrm{~B}-\mathrm{C}$ & $1.6 \mathrm{~A}-\mathrm{D}$ & $0.33 \mathrm{~A}-\mathrm{D}$ \\
\hline 5 & IG 128113 & $2.97 \mathrm{C}-\mathrm{F}$ & $0.26 \mathrm{G}-\mathrm{L}$ & $1.65 \mathrm{E}$ & $1.0 \mathrm{~J}-\mathrm{M}$ & $0.29 \mathrm{D}-\mathrm{I}$ \\
\hline 6 & IG 128116 & 3.61A-E & $0.33 \mathrm{~A}-\mathrm{B}$ & $2.03 \mathrm{~B}-\mathrm{C}$ & $0.9 \mathrm{M}$ & $0.26 \mathrm{G}-\mathrm{K}$ \\
\hline 7 & IG 128120 & $3.68 \mathrm{~A}-\mathrm{C}$ & $0.26 \mathrm{H}-\mathrm{L}$ & $1.55 \mathrm{E}-\mathrm{F}$ & $1.78 \mathrm{~A}$ & $0.34 \mathrm{~A}-\mathrm{C}$ \\
\hline 8 & IG 128134 & $3.70 \mathrm{~A}-\mathrm{B}$ & $0.29 \mathrm{D}-\mathrm{F}$ & $1.88 \mathrm{D}$ & $1.3 \mathrm{G}-\mathrm{I}$ & $0.23 \mathrm{~J}-\mathrm{K}$ \\
\hline 9 & IG 128135 & $2.59 \mathrm{E}-\mathrm{G}$ & $0.28 \mathrm{D}-\mathrm{H}$ & $1.58 \mathrm{E}-\mathrm{F}$ & $1.3 \mathrm{G}-\mathrm{I}$ & $0.32 \mathrm{~A}-\mathrm{F}$ \\
\hline 10 & IG 128136 & $3.68 \mathrm{~A}-\mathrm{C}$ & $0.35 \mathrm{~A}$ & $1.84 \mathrm{D}$ & $1.3 \mathrm{~F}-\mathrm{I}$ & $0.32 \mathrm{~A}-\mathrm{F}$ \\
\hline 11 & IG 128190 & $2.53 \mathrm{~F}-\mathrm{G}$ & 0.27 E-K & $1.88 \mathrm{D}$ & $1.4 \mathrm{D}-\mathrm{G}$ & $0.25 \mathrm{I}-\mathrm{K}$ \\
\hline 12 & IG 18801 & $2.92 \mathrm{D}-\mathrm{F}$ & $0.25 \mathrm{I}-\mathrm{L}$ & $0.81 \mathrm{I}$ & $1.0 \mathrm{~L}-\mathrm{M}$ & $0.24 \mathrm{I}-\mathrm{K}$ \\
\hline 13 & IG 18842 & $2.85 \mathrm{D}-\mathrm{F}$ & $0.19 \mathrm{~N}-\mathrm{O}$ & $0.85 \mathrm{I}$ & $1.1 \mathrm{E}-\mathrm{H}$ & $0.21 \mathrm{~K}-\mathrm{L}$ \\
\hline 14 & IG 19097 & $2.79 \mathrm{D}-\mathrm{F}$ & $0.25 \mathrm{~J}-\mathrm{L}$ & $1.10 \mathrm{H}$ & $1.0 \mathrm{~J}-\mathrm{M}$ & $0.21 \mathrm{~K}-\mathrm{L}$ \\
\hline 15 & IG 19110 & $2.91 \mathrm{D}-\mathrm{F}$ & $0.24 \mathrm{~K}-\mathrm{M}$ & $0.82 \mathrm{I}$ & $1.2 \mathrm{H}-\mathrm{J}$ & $0.23 \mathrm{~J}-\mathrm{K}$ \\
\hline 16 & IG 28579 & $2.93 \mathrm{D}-\mathrm{F}$ & $0.22 \mathrm{M}-\mathrm{N}$ & $0.92 \mathrm{I}$ & $1.3 \mathrm{G}-\mathrm{I}$ & $0.24 \mathrm{I}-\mathrm{K}$ \\
\hline 17 & IG 28582 & $2.89 \mathrm{D}-\mathrm{F}$ & $0.26 \mathrm{~F}-\mathrm{L}$ & $1.50 \mathrm{~F}$ & $1.5 \mathrm{~B}-\mathrm{E}$ & $0.32 \mathrm{~A}-\mathrm{F}$ \\
\hline 18 & IG 28588 & $2.83 \mathrm{D}-\mathrm{F}$ & $0.24 \mathrm{~K}-\mathrm{M}$ & $1.16 \mathrm{H}$ & $1.5 \mathrm{C}-\mathrm{F}$ & $0.30 \mathrm{~B}-\mathrm{H}$ \\
\hline 19 & IG 28596 & $3.46 \mathrm{~A}-\mathrm{D}$ & 0.27 E-J & $1.12 \mathrm{H}$ & $1.1 \mathrm{I}-\mathrm{L}$ & $0.30 \mathrm{~B}-\mathrm{G}$ \\
\hline 20 & IG 28715 & $3.68 \mathrm{~A}-\mathrm{C}$ & 0.27 E-J & $1.31 \mathrm{G}$ & $1.2 \mathrm{H}-\mathrm{J}$ & $0.32 \mathrm{~A}-\mathrm{E}$ \\
\hline 21 & IG 128078 & $3.78 \mathrm{~A}$ & $0.31 \mathrm{~B}-\mathrm{D}$ & 1.95 C-D & $1.0 \mathrm{~J}-\mathrm{M}$ & $0.36 \mathrm{~A}$ \\
\hline 22 & IG 128079 & $2.81 \mathrm{D}-\mathrm{F}$ & $0.31 \mathrm{~B}-\mathrm{D}$ & $1.33 \mathrm{G}$ & $1.2 \mathrm{H}-\mathrm{K}$ & $0.35 \mathrm{~A}-\mathrm{B}$ \\
\hline 23 & IG 128080 & 2.74 E-F & 0.28 E-J & $2.12 \mathrm{~B}$ & $1.1 \mathrm{~J}-\mathrm{M}$ & $0.34 \mathrm{~A}-\mathrm{C}$ \\
\hline 24 & IG 128081 & $2.54 \mathrm{~F}-\mathrm{G}$ & 0.28 E-J & $2.11 \mathrm{~B}$ & $1.0 \mathrm{~J}-\mathrm{M}$ & 0.29 C-I \\
\hline 25 & IG 128083 & $2.63 \mathrm{E}-\mathrm{G}$ & $0.32 \mathrm{~A}-\mathrm{C}$ & $2.40 \mathrm{~A}$ & $0.9 \mathrm{M}$ & 0.27 F-J \\
\hline 26 & IG 128166 & $2.80 \mathrm{D}-\mathrm{F}$ & $0.30 \mathrm{C}-\mathrm{E}$ & $1.55 \mathrm{E}-\mathrm{F}$ & $1.3 \mathrm{G}-\mathrm{I}$ & 0.28 E-J \\
\hline 27 & IG 128180 & $3.00 \mathrm{~B}-\mathrm{F}$ & $0.28 \mathrm{D}-\mathrm{I}$ & $1.11 \mathrm{H}$ & $1.0 \mathrm{~K}-\mathrm{M}$ & $0.17 \mathrm{~L}$ \\
\hline 28 & IG 128192 & $2.02 \mathrm{G}$ & $0.24 \mathrm{~L}-\mathrm{M}$ & $1.17 \mathrm{H}$ & $1.7 \mathrm{~A}-\mathrm{B}$ & $0.23 \mathrm{~J}-\mathrm{K}$ \\
\hline
\end{tabular}

Değerler 3 tekerrür ortalamasıdır. Aynı harflerle gösterilmeyen değerler arasındaki farklar \%5 düzeyinde önemlidir. 1-2 Sıra numaralı çeşitler tescilli çeşitleri göstermektedir. 3-11 Sıra numaralı çeşitler Akdeniz Bölgesi'ne ait yerel arpa çeşitlerini göstermektedir. 12-28 Sıra numaralı çeşitler Ege Bölgesi’ne ait yerel arpa çeşitlerini göstermektedir.

Çizelge 4. Yaprak örneklerinin mikro besin element içerikleri.

Table 4. Micronutrient element contents of leaf samples.

\begin{tabular}{|c|c|c|c|c|c|}
\hline Sira No & Çeşitler & Demir (ppm) & Mangan (ppm) & Çinko (ppm) & Bakır (ppm) \\
\hline 1 & Bülbül 89 & $89.5 \mathrm{~F}-\mathrm{K}$ & $43.0 \mathrm{~L}-\mathrm{N}$ & $5.3 \mathrm{~N}$ & $13.3 \mathrm{~B}$ \\
\hline 2 & Akhisar98 & $97.8 \mathrm{E}-\mathrm{K}$ & $84.2 \mathrm{~B}$ & $6.4 \mathrm{M}-\mathrm{N}$ & $5.5 \mathrm{~F}-\mathrm{I}$ \\
\hline 3 & IG 128075 & 127.6 C-D & $51.1 \mathrm{I}-\mathrm{L}$ & $20.5 \mathrm{~A}-\mathrm{B}$ & $26.9 \mathrm{~A}$ \\
\hline 4 & IG 128111 & $81.8 \mathrm{I}-\mathrm{K}$ & $169.5 \mathrm{~A}$ & $21.4 \mathrm{~A}$ & $4.8 \mathrm{H}-\mathrm{I}$ \\
\hline 5 & IG 128113 & $157.0 \mathrm{~B}$ & 54.0 G-J & $10.0 \mathrm{H}-\mathrm{K}$ & $5.8 \mathrm{E}-\mathrm{I}$ \\
\hline 6 & IG 128116 & $75.8 \mathrm{~J}-\mathrm{K}$ & $35.5 \mathrm{~N}$ & $8.7 \mathrm{I}-\mathrm{L}$ & $5.1 \mathrm{G}-\mathrm{I}$ \\
\hline 7 & IG 128120 & $70.5 \mathrm{~K}$ & 79.9 B-C & 16.8 C-D & 5.7 E-I \\
\hline 8 & IG 128134 & 111.7 C-G & $63.2 \mathrm{E}-\mathrm{F}$ & $11.1 \mathrm{G}-\mathrm{H}$ & $5.3 \mathrm{~F}-\mathrm{I}$ \\
\hline 9 & IG 128135 & 99.4 E-J & $63.3 \mathrm{E}-\mathrm{F}$ & $8.1 \mathrm{~J}-\mathrm{M}$ & 5.7 E-I \\
\hline 10 & IG 128136 & $192.9 \mathrm{~A}$ & $51.4 \mathrm{I}-\mathrm{L}$ & $10.5 \mathrm{H}-\mathrm{I}$ & $6.5 \mathrm{C}-\mathrm{H}$ \\
\hline 11 & IG 128190 & 118.4 C-E & 69.3 D-E & $8.0 \mathrm{~K}-\mathrm{M}$ & 5.7 E-I \\
\hline 12 & IG 18801 & $88.0 \mathrm{G}-\mathrm{K}$ & $37.2 \mathrm{M}-\mathrm{N}$ & $11.4 \mathrm{G}-\mathrm{H}$ & $8.7 \mathrm{C}$ \\
\hline 13 & IG 18842 & 104.0 D-I & 53.9 G-J & 7.2 L-N & 6.3 D-I \\
\hline 14 & IG 19097 & $85.2 \mathrm{G}-\mathrm{K}$ & $36.7 \mathrm{~N}$ & 17.4 C-D & 7.7 C-E \\
\hline 15 & IG 19110 & $91.8 \mathrm{E}-\mathrm{K}$ & $35.7 \mathrm{~N}$ & $11.5 \mathrm{G}-\mathrm{H}$ & $6.9 \mathrm{C}-\mathrm{H}$ \\
\hline 16 & IG 28579 & 91.5 E-K & $50.7 \mathrm{I}-\mathrm{L}$ & 10.8 G-I & 5.6 E-I \\
\hline 17 & IG 28582 & 108.8 C-I & 57.7 F-I & $12.1 \mathrm{~F}-\mathrm{H}$ & 6.2 D-I \\
\hline 18 & IG 28588 & 95.8 E-K & $62.0 \mathrm{E}-\mathrm{G}$ & $13.8 \mathrm{E}-\mathrm{F}$ & $7.2 \mathrm{C}-\mathrm{G}$ \\
\hline 19 & IG 28596 & $117.3 \mathrm{C}-\mathrm{F}$ & $45.4 \mathrm{~J}-\mathrm{M}$ & $6.4 \mathrm{M}-\mathrm{N}$ & $12.8 \mathrm{~B}$ \\
\hline 20 & IG 28715 & $82.3 \mathrm{H}-\mathrm{K}$ & $43.7 \mathrm{~K}-\mathrm{N}$ & 10.2 H-J & 7.4 C-F \\
\hline 21 & IG 128078 & $112.3 \mathrm{C}-\mathrm{G}$ & $62.7 \mathrm{E}-\mathrm{F}$ & 17.3 C-D & 8.2 C-D \\
\hline 22 & IG 128079 & $133.5 \mathrm{~B}-\mathrm{C}$ & 69.4 D-E & $21.8 \mathrm{~A}$ & $6.6 \mathrm{C}-\mathrm{H}$ \\
\hline 23 & IG 128080 & 117.8 C-E & $60.2 \mathrm{~F}-\mathrm{H}$ & 18.7 B-C & 5.7 E-I \\
\hline 24 & IG 128081 & $88.0 \mathrm{G}-\mathrm{K}$ & $52.1 \mathrm{H}-\mathrm{K}$ & $21.3 \mathrm{~A}$ & $5.2 \mathrm{G}-\mathrm{I}$ \\
\hline 25 & IG 128083 & $82.0 \mathrm{H}-\mathrm{K}$ & $72.6 \mathrm{C}-\mathrm{D}$ & $17.8 \mathrm{C}$ & 6.0 D-I \\
\hline 26 & IG 128166 & 98.1 E-K & 53.8 G-J & 15.6 D-E & $4.3 \mathrm{I}$ \\
\hline 27 & IG 128180 & $75.6 \mathrm{~J}-\mathrm{K}$ & $41.9 \mathrm{M}-\mathrm{N}$ & $12.9 \mathrm{~F}-\mathrm{G}$ & $4.9 \mathrm{H}-\mathrm{I}$ \\
\hline 28 & IG 128192 & $109.9 \mathrm{C}-\mathrm{H}$ & 69.2 D-E & $6.0 \mathrm{M}-\mathrm{N}$ & 7.5 C-F \\
\hline
\end{tabular}

Değerler 3 tekerrür ortalamasıdır. Aynı harflerle gösterilmeyen değerler arasındaki farklar \%5 düzeyinde önemlidir. 1-2 Sıra numaralı çeşitler tescilli çeşitleri göstermektedir. 3-11 Sıra numaralı çeşitler Akdeniz Bölgesi’ne ait yerel arpa çeşitlerini göstermektedir. 12-28 Sıra numaralı çeşitler Ege Bölgesi'ne ait yerel arpa çeşitlerini göstermektedir. 
ile karşılaştırıldığında \%100'ünün yeterli düzeyde Fe içerdiği belirlenmiştir.

Mangan içerikleri bakımından yerel arpa çeşitlerinin yaprak örnekleri değerlendirildiğinde en yüksek Mn konsantrasyonu 169.5 ppm ile IG 128111 numaralı çeşitte, en düşük Mn konsantrasyonu 35.5 ppm ile IG 128116 numaralı çeşitte belirlenmiştir. Bülbül-89 referans çeşidi 43.0 ppm Mn içeriği ile yerel arpa çeşitlerine göre daha düşük, Akhisar-98 çeşidi ise 84.2 ppm Mn içeriği ile yerel arpa çeşitlerine yakın Mn içeriğine sahip olmuştur (Çizelge 4). Yaprak örneklerinin analiz sonuçları Jones ve ark. (1991) tarafindan yeterli olarak belirlenen 25-100 ppm sınır değerleri ile karşılaştırıldığında \%96.4'ünün yeterli, \%3.6'sının ise yüksek düzeyde Mn içerdiği belirlenmiştir.

Çinko içerikleri bakımından yerel arpa çeşitlerinin yaprak örnekleri değerlendirildiğinde en yüksek $\mathrm{Zn}$ konsantrasyonu 21.8 ppm ile IG 128079 numaralı çeşitte, en düşük $\mathrm{Zn}$ konsantrasyonu $6.0 \mathrm{ppm}$ ile IG 128192 numaralı çeşitte belirlenmiştir. Bülbül-89 (5.3ppm) ve Akhisar-98 (6.4 ppm) çeşitleri yerel arpa çeşitlerine göre daha düşük $\mathrm{Zn}$ içeriğine sahip olmuşlardır (Çizelge 4). Yaprak örneklerinin analiz sonuçları Jones ve ark. (1991) tarafindan yeterli olarak belirlenen 15-70 ppm sınır değerleri ile karşılaştırıldığında \%64.3'ünün noksan ve \%35.7'sinin yeterli düzeyde $\mathrm{Zn}$ içerdiği belirlenmiş̧tir.

Bakır içerikleri bakımından yerel arpa çeşitlerinin yaprak örnekleri değerlendirildiğinde en yüksek $\mathrm{Cu}$ konsantrasyonu 26.9 ppm ile IG 128075 numaralı çeşitte, en düşük $\mathrm{Cu}$ konsantrasyonu 4.3 ppm ile IG 128166 numaralı çeşitte belirlenmiştir. Referans çeşitlerinden Bülbül-89 (13.0 ppm) yerel çeşitlere göre daha yüksek, Akhisar-98 (5.5 ppm) çeşidi ise yerel arpa çeşitlerine yakın $\mathrm{Cu}$ içeriğine sahip olmuştur (Çizelge 4). Yaprak örneklerinin analiz sonuçları Jones ve ark. (1991) tarafindan yeterli olarak belirlenen 5-25 ppm sinır değerleri ile karşılaştırıldığında \%10.7'sinin noksan, $\% 85.7$ 'sinin yeterli ve \%3.6'sının ise yüksek düzeyde $\mathrm{Cu}$ içerdiği belirlenmiştir.

\subsection{Dane örneklerinin makro ( $N, P, K$, Cave $M g$ ) ve mikro ( $F e$, $\mathrm{Mn}, \mathrm{Zn}$ ve $\mathrm{Cu}$ ) element analiz sonuçları}

Yerel arpa çeşitlerinin dane örnekleri toplam $\mathrm{N}$ içerikleri bakımından incelendiğinde; en yüksek toplam $\mathrm{N}$ içeriğgi $\% 2.54$ ile IG 128180 numaralı çeşitte, en düşük toplam N içeriği $\% 1.65$ ile IG 128081 numaralı çeşitte belirlenmiştir. Bülbül-89 (\%2.44) ve Akhisar-98 (\%2.15) çeşitleri ise yerel arpa çeşitlerine yakın toplam $\mathrm{N}$ içeriklerine sahip olmuşlardır (Çizelge 5).

Yerel arpa çeşitlerinin dane örnekleri $\mathrm{P}$ içerikleri bakımından incelendiğinde; en yüksek P içeriği 5993 ppm ile IG 128078 numaralı çeşitte, en düşük P içeriği 3476 ppm ile IG 28582 numaralı çeşitte belirlenmiştir. Kontrol çeşitlerinden Bülbül-89 (4317 ppm) ve Akhisar-98'in ise (3883 ppm) yerel arpa çeşitlerinin çoğuna göre daha düşük $\mathrm{P}$ içeriğine sahip oldukları belirlenmiştir (Çizelge 5). Altuntaş (2012) Tokak yerel arpa çeşidi içinden seçilen arpa hatlarının $\mathrm{P}$ içeriklerinin 3011.2-3679.3 ppm arasında değiştiğini, Alkan ve Kandemir (2015) Türkiye'de yaygın bir şekilde yetiştirilen Tokak 157/37 arpa çeşidinin P içeriğinin 3898.6 ppm olduğunu, dünya da çok

Çizelge 5. Dane örneklerinin makro besin element içerikleri.

Table 5. Macro nutrient content of grain samples.

\begin{tabular}{|c|c|c|c|c|c|c|}
\hline Sira No & Çeşitler & $\mathbf{N}(\%)$ & $\mathbf{P}(\mathbf{p p m})$ & K (ppm) & Ca (ppm) & Mg (ppm) \\
\hline 1 & Bülbül 89 & $2.44 \mathrm{~A}-\mathrm{C}$ & 4317 F-J & $1065 \mathrm{~N}-\mathrm{O}$ & 796 I-J & $1618 \mathrm{~F}-\mathrm{G}$ \\
\hline 2 & Akhisar98 & 2.15 F-I & $3883 \mathrm{~J}-\mathrm{L}$ & $962 \mathrm{O}$ & $1610 \mathrm{~A}$ & $1708 \mathrm{D}-\mathrm{G}$ \\
\hline 3 & IG 128075 & $2.11 \mathrm{G}-\mathrm{J}$ & $4096 \mathrm{H}-\mathrm{K}$ & 2613 H-J & 1384 A-C & $1600 \mathrm{~F}-\mathrm{H}$ \\
\hline 4 & IG 128111 & $2.11 \mathrm{G}-\mathrm{J}$ & 4351 E-J & 3896 C-E & $1400 \mathrm{~A}-\mathrm{C}$ & $1670 \mathrm{~F}-\mathrm{G}$ \\
\hline 5 & IG 128113 & $2.04 \mathrm{I}-\mathrm{L}$ & $4669 \mathrm{C}-\mathrm{F}$ & 3787 C-E & $1220 \mathrm{~B}-\mathrm{F}$ & $1789 \mathrm{C}-\mathrm{G}$ \\
\hline 6 & IG 128116 & $2.36 \mathrm{~B}-\mathrm{E}$ & $4593 \mathrm{C}-\mathrm{H}$ & $4911 \mathrm{~B}$ & $1153 \mathrm{~B}-\mathrm{G}$ & $1684 \mathrm{E}-\mathrm{G}$ \\
\hline 7 & IG 128120 & $1.81 \mathrm{~N}$ & $5210 \mathrm{~B}$ & $3738 \mathrm{C}-\mathrm{E}$ & $1616 \mathrm{~A}$ & $2131 \mathrm{~A}-\mathrm{B}$ \\
\hline 8 & IG 128134 & $2.29 \mathrm{C}-\mathrm{F}$ & 4652 C-F & 2925 H-I & $1157 \mathrm{~B}-\mathrm{G}$ & $1835 \mathrm{C}-\mathrm{F}$ \\
\hline 9 & IG 128135 & $1.82 \mathrm{M}-\mathrm{N}$ & 3958 I-L & 3994 C-E & $1117 \mathrm{C}-\mathrm{G}$ & $1766 \mathrm{C}-\mathrm{G}$ \\
\hline 10 & IG 128136 & $2.41 \mathrm{~A}-\mathrm{D}$ & 4909 B-D & $6319 \mathrm{~A}$ & 995 E-J & 2142 A-B \\
\hline 11 & IG 128190 & $2.11 \mathrm{G}-\mathrm{J}$ & $4613 \mathrm{C}-\mathrm{G}$ & 4102 C-D & 1262 B-E & 1974 B-C \\
\hline 12 & IG 18801 & $2.23 \mathrm{E}-\mathrm{G}$ & 4357 E-J & $1284 \mathrm{~N}-\mathrm{O}$ & 1072 E-I & $1661 \mathrm{~F}-\mathrm{G}$ \\
\hline 13 & IG 18842 & $2.06 \mathrm{H}-\mathrm{K}$ & 4313 F-J & $1156 \mathrm{~N}-\mathrm{O}$ & 1098 D-H & 1704 D-G \\
\hline 14 & IG 19097 & 2.11 G-J & $3520 \mathrm{~L}$ & $1386 \mathrm{M}-\mathrm{O}$ & 926 G-J & $1368 \mathrm{H}$ \\
\hline 15 & IG 19110 & 2.49 A-B & 4746 B-F & $1500 \mathrm{M}-\mathrm{N}$ & 1059 E-I & $1751 \mathrm{C}-\mathrm{G}$ \\
\hline 16 & IG 28579 & $1.97 \mathrm{~J}-\mathrm{M}$ & $4121 \mathrm{G}-\mathrm{K}$ & 2063 K-L & $1400 \mathrm{~A}-\mathrm{C}$ & $1548 \mathrm{G}-\mathrm{H}$ \\
\hline 17 & IG 28582 & $1.93 \mathrm{~K}-\mathrm{N}$ & $3476 \mathrm{~L}$ & $2101 \mathrm{~J}-\mathrm{L}$ & $1361 \mathrm{~A}-\mathrm{D}$ & $1707 \mathrm{D}-\mathrm{G}$ \\
\hline 18 & IG 28588 & $1.90 \mathrm{~L}-\mathrm{N}$ & $3693 \mathrm{~K}-\mathrm{L}$ & 1844 L-M & 968 F-J & $1604 \mathrm{~F}-\mathrm{H}$ \\
\hline 19 & IG 28596 & $2.05 \mathrm{H}-\mathrm{K}$ & 3949 I-L & $3525 \mathrm{E}-\mathrm{G}$ & 802 I-J & $1570 \mathrm{G}-\mathrm{H}$ \\
\hline 20 & IG 28715 & $2.20 \mathrm{E}-\mathrm{H}$ & 4788 B-F & $2738 \mathrm{H}-\mathrm{I}$ & $725 \mathrm{~J}$ & $1731 \mathrm{C}-\mathrm{G}$ \\
\hline 21 & IG 128078 & $2.41 \mathrm{~A}-\mathrm{D}$ & $5993 \mathrm{~A}$ & 2886 H-I & $831 \mathrm{H}-\mathrm{J}$ & $2151 \mathrm{~A}-\mathrm{B}$ \\
\hline 22 & IG 128079 & 2.15 F-I & $5892 \mathrm{~A}$ & 3065 F-H & 1268 B-E & $2261 \mathrm{~A}$ \\
\hline 23 & IG 128080 & $1.92 \mathrm{~K}-\mathrm{N}$ & 4847 B-E & $2408 \mathrm{I}-\mathrm{K}$ & $1128 \mathrm{C}-\mathrm{G}$ & 1955 B-D \\
\hline 24 & IG 128081 & $1.65 \mathrm{O}$ & $4699 \mathrm{C}-\mathrm{F}$ & 3014 G-H & 1428 A-B & 1940 B-D \\
\hline 25 & IG 128083 & $2.28 \mathrm{D}-\mathrm{F}$ & $5025 \mathrm{~B}-\mathrm{C}$ & $3578 \mathrm{D}-\mathrm{F}$ & 968 F-J & 1977 B-C \\
\hline 26 & IG 128166 & $1.80 \mathrm{~N}-\mathrm{O}$ & 4447 D-I & 3678 C-E & 1024 E-I & 1734 C-G \\
\hline 27 & IG 128180 & $2.54 \mathrm{~A}$ & 4779 B-F & 3843 C-E & $1187 \mathrm{~B}-\mathrm{G}$ & $1778 \mathrm{C}-\mathrm{G}$ \\
\hline 28 & IG 128192 & $2.01 \mathrm{I}-\mathrm{L}$ & $4595 \mathrm{C}-\mathrm{H}$ & $4130 \mathrm{C}$ & 1274 B-E & 1929 B-E \\
\hline
\end{tabular}

Değerler 3 tekerrür ortalamasıdır. Aynı harflerle gösterilmeyen değerler arasındaki farklar \%5 düzeyinde önemlidir. 1-2 Sıra numaralı çeșitler tescilli çeșitleri göstermektedir. 3-11 Sıra numaralı çeşitler Akdeniz Bölgesi'ne ait yerel arpa çeşitlerini göstermektedir. 12-28 Sıra numaralı çeşitler Ege Bölgesi'ne ait yerel arpa çeşitlerini göstermektedir. 
iyi bir maltlık arpa çeşidi olan Harrington arpa çeşidinin $\mathrm{P}$ içeriğinin ise $2690.8 \mathrm{ppm}$ olduğunu, Villacres ve Rivadeneira (2005) arpada P içeriğinin 2400-4700 ppm arasında değiştiğini bildirmişlerdir. Yapılan çalışmalar ile yerel arpa çeşitlerinin dane bileşimi değerlendirildiğinde yerel arpa çeşitlerinin $\mathrm{P}$ içeriği bakımından zengin olduğu düşünülmektedir.

İncelenen yerel arpa çeşitleri dane $\mathrm{K}$ içeriği bakımından değerlendirildiğinde; en yüksek K içeriği 6319 ppm ile IG 128136 numaralı çeşitte, en düşük $\mathrm{K}$ içeriği 1156 ppm ile IG 18842 numaralı çeşitte belirlenmiştir. Referans çeşitlerinden Bülbül-89 (1065 ppm) yerel çeşitlere göre nispeten daha düşük K içeriğine sahip olurken, Akhisar-98 (962 ppm) en düşük K içeriğine sahip olmuştur. Sonuçlar incelendiğinde yerel arpa çeşitlerinin referans çeşitlerine göre $\mathrm{K}$ bakımından zengin olduğu anlaşılmaktadır(Çizelge 5). Alkan ve Kandemir (2015) Tokak $157 / 37$ arpa çeşidinin $\mathrm{K}$ içeriğinin 4526.6ppm ve Harrington arpa çeşidinin $\mathrm{K}$ içeriğinin ise $3720.7 \mathrm{ppm}$ olduğunu, Villacres ve Rivadeneira (2005) arpanın K içeriğinin 2200-4800 ppm arasında değiştiğini, Altuntaş (2012) Tokak yerel arpa çeşidi içinden seçilen arpa hatlarının $\mathrm{K}$ içeriğinin 3886.4-4742.7 ppm arasında değiştiğini bildirmişlerdir. Yapılan çalışmalarla yerel arpa çeşitleri $\mathrm{K}$ içerikleri bakımından değerlendirildiğinde; IG 18801, IG 18842, IG 19097, IG 19110 , IG 28579, IG 28582 ve IG 28588 numaralı yerel arpa çeşitlerinin daha düşük $\mathrm{K}$ içeriğine sahip olduğu, geriye kalan yerel arpa çeşitlerinin ise çalışmalarla uyumlu olduğu belirlenmiştir.

İncelenen yerel arpa çeşitleri dane $\mathrm{Ca}$ içeriği bakımından incelendiğinde en yüksek Ca içeriği 1616 ppm ile IG 128120 numaralı çeşitte, en düşük Ca içeriği ise 725 ppm ile IG 28715 numaralı çeşitte belirlenmiștir. Referans çeșitlerinden Bülbül-89 çeşidi 796 ppm Ca içeriğine, Akhisar-98 çeşidi ise 1610 ppm Ca içeriğine sahip olmuştur. Yerel arpa çeşitleri Akhisar-98 çeşidine göre daha düşük $\mathrm{Ca}$ içeriğine sahip olurken, Bülbül-89 çeşidine göre daha yüksek $\mathrm{Ca}$ içeriğine sahip olmuşlardır (Çizelge 5). Alkan ve Kandemir (2015) Tokak 157/37 arpa çeşidinin $\mathrm{Ca}$ içeriğinin 325.5 ppm ve Harrington arpa çeşidinin Ca içeriğinin ise 422.7 ppm olduğunu, Altuntaş (2012) Tokak yerel arpa çeşidi içinden seçilen arpa hatlarının $\mathrm{Ca}$ içeriğinin 306.7-428.7 ppm arasında değiştiğini bildirmişlerdir. Carr ve ark. (2004) iki sıralı üç arpa çeşidinin tanelerinin Ca miktarlarını incelemişler ve tanelerin 295 ppm ile 365 ppm arasında değişen miktarlarda $\mathrm{Ca}$ içeriğine sahip olduğunu bildirmişlerdir. Yerel arpa çeşitlerinde yapılan bu çalışma ile benzer şekilde yapılan çalışmaların $\mathrm{Ca}$ miktarlarının örtüşmemesinin nedenini çalışmanın yapıldığı deneme alanı toprağının yüksek $\mathrm{Ca}$ içeriğinin yüksekliğine dayandırılmıştır.

İncelenen yerel arpa çeşitleri dane $\mathrm{Mg}$ içeriği bakımından incelendiğinde en yüksek Mg içeriği 2261 ppm ile IG 128079 numaralı çeşitte, en düşük $\mathrm{Mg}$ içeriği ise 1368 ppm ile IG 19097 numaralı çeşitte belirlenmiştir. Referans çeşitlerinden Bülbül-89 çeşidinin Mg içeriği 1618 ppm, Akhisar-98 çeşidinin $\mathrm{Mg}$ içeriği ise $1708 \mathrm{ppm}$ olarak belirlenmiştir. Yerel arpa çeşitlerinin referans çeşitlerine göre yüksek $\mathrm{Mg}$ içeriğine sahip oldukları belirlenmiştir (Çizelge 5). Altuntaş (2012) Tokak yerel arpa çeşidi içinden seçilen arpa hatlarının Mg içeriğinin 1214.11439.1 ppm arasında değiştiğini, Alkan ve Kandemir (2015) Tokak 157/37 arpa çeşidinin Mg içeriğinin 1373.4 ppm ve Harrington arpa çeşidinin $\mathrm{Mg}$ içeriğinin ise $1161.5 \mathrm{ppm}$ olduğunu bildirmişlerdir. Daha önceki çalışmalarda, araştırıcılar arpa tanesinin $\mathrm{Mg}$ içeriğinin $1200 \mathrm{ppm}$ ile 1600 ppm arasında değiştiğini bildirmişlerdir (Byrne ve Rasmusson 1974). Bu sonuçlar ile yerel arpa çeşitleri kıyaslandığında yerel arpa çeşitlerinin $\mathrm{Mg}$ içeriği bakımından zengin oldukları sonucuna varılmıştır.

Yerel arpa çeşitlerinin dane örnekleri $\mathrm{Fe}$ içerikleri bakımından değerlendirildiğinde en yüksek Fe içeriği 75.1 ppm ile IG 28715 numaralı çeşitte, en düşük Fe içeriği 22.7 ppm ile IG 128180 numaralı çeşitte belirlenmiştir. Referans çeşitlerinden Bülbül-89 (26.4ppm) yerel arpa çeşitlerine göre nispeten daha düşük $\mathrm{Fe}$ içeriğine sahip olurken, Akhisar-98 (59.3 ppm) çeşidi ise yerel arpa çeşitlerinin çoğuna göre daha yüksek $\mathrm{Fe}$ içeriğine sahip olmuştur (Çizelge 6). Kandemir ve ark. (2005) beş arpa çeşidini mineral madde yönleriyle incelemiş ve bunlar içerisinden Harrington'un Fe içeriğinin 44.8 ppm olduğunu, Altuntaş (2012) Tokak yerel arpa çeşidi içinden seçilen arpa hatlarının Fe içeriklerinin 24.8-44.5 ppm arasında değiştiğini, Alkan ve Kandemir (2015), Tokak 157/37 arpa çeşidinin Fe içeriğinin 32.7 ppm ve Harrington arpa çeşidinin $\mathrm{Fe}$ içeriğinin ise $36.0 \mathrm{ppm}$ olduğunu, Villacres ve Rivadeneira (2005), yaptıkları çalışmada arpa tanesinde Fe içeriğinin 26-72 ppm arasında değiştiğini bildirmişlerdir. Yapılan çalışmalar ile yerel arpa çeşitlerinden elde edilen sonuçlar paralellik göstermektedir.

Mangan içerikleri bakımından yerel arpa çeşitlerinin dane örnekleri değerlendirildiğinde; en yüksek Mn içeriği 22.1 ppm ile IG 128120 numaralı çeşitte, en düşük Mn içeriği 12.0 ppm ile IG 18842 numaralı çeşitte belirlenmiştir. Referans çeşitleri Bülbül-89 (14.0 ppm) ve Akhisar-98 (17.4 ppm) çeşitleri yerel arpa çeşitlerine yakın Mn içeriğine sahip olmuşlardır (Çizelge 6). Alkan ve Kandemir (2015) Tokak 157/37 arpa çeşidinin Mn içeriğinin 15.8 ppm ve Harrington arpa çeşidinin Mn içeriğinin ise $15.8 \mathrm{ppm}$ olduğunu, Kandemir ve ark. (2005) arpa çeşitlerinde Mn içeriğinin 8-11.4 ppm arasında değiştiğini, Altuntaş (2012) Tokak yerel arpa çeşidi içinden seçilen arpa hatlarının Mn içeriğinin 15.4-21.2 ppm arasında değiştiğini bildirmişlerdir. Yapılan çalışmaların sonuçları ile yerel arpa çeşitlerinden elde edilen sonuçlar karşılaştırıldığında paralellik göstermektedir.

Çinko içerikleri bakımından yerel arpa çeşitlerinin dane örnekleri değerlendirildiğinde; en yüksek Zn içeriği 43.3 ppm ile IG 128078 numaralı çeşitte, en düşük Zn içeriği 16.9 ppm ile IG 128135 numaralı çeşitte belirlenmiştir. Bülbül-89 referans çeşidi 33.5 ppm Zn içeriği ile yerel çeşitlerin çoğundan yüksek, Akhisar-98 çeşidi ise $26.3 \mathrm{ppm} \mathrm{Zn}$ içeriği ile yerel çeşitlere yakın $\mathrm{Zn}$ içeriğine sahip olmuştur (Çizelge 6). Alkan ve Kandemir (2015) Tokak $157 / 37$ arpa çeşidinin Zn içeriğinin $47.8 \mathrm{ppm}$ olduğunu ve Harrington arpa çeşidinin $\mathrm{Zn}$ içeriğinin ise 28.8 ppm olduğunu, Villacres ve Rivadeneira (2005) arpa Zn içeriklerinin 30-50 ppm arasında değiştiğini, Altuntaş (2012) Tokak yerel arpa çeşidi içinden seçilen arpa hatlarının $\mathrm{Zn}$ içeriğinin 28.4-39.6 ppm arasında değiştiğini bildirmişlerdir. Yapılan çalışmalardan elde edilen sonuçlar ile yerel arpa çeşitlerinden elde edilen sonuçlar paralellik göstermektedir.

Bakır içerikleri yönüyle yerel çeşitlerin dane örnekleri incelendiğinde en yüksek Cu içeriği 4.4 ppm ile IG 128079 ve IG 128111 numaralı çeşitlerde, en düşük $\mathrm{Cu}$ içeriği ise $2.2 \mathrm{ppm}$ ile IG 19097 numaralı çeşitte belirlenmiştir. Bülbül-89 referans çeşidi 3.7 ppm Cu içeriği ile yerel çeşitlerin çoğundan yüksek, Akhisar-98 çeşidi ise $4.0 \mathrm{ppm} \mathrm{Cu}$ içeriği ile yerel çeşitlerin çoğundan yüksek $\mathrm{Cu}$ içeriğine sahip olmuştur (Çizelge 6). Altuntaş (2012) Tokak yerel arpa çeşidi içinden seçilen arpa hatlarının $\mathrm{Cu}$ içeriğinin 5.4 ppm ile $8.5 \mathrm{ppm}$ arasında değiştiğini, Alkan ve Kandemir (2015) Tokak 157/37 arpa çeşidinin $\mathrm{Cu}$ içeriğinin 6.25 ppm olduğunu ve Harrington arpa çeşidinin $\mathrm{Cu}$ içeriğinin ise $5.57 \mathrm{ppm}$ olduğunu, Kandemir ve 
ark. (2005) beş çeşit arpanın $\mathrm{Cu}$ içeriklerinin 3.0-6.4 ppm arasında değiştiğini bildirmişlerdir. $\mathrm{Bu}$ sonuçlar ile yapılan çalışmanın sonuçları benzerlik göstermektedir.

\subsection{Dane örneklerinin protein analiz sonuçları}

Proteinler; dokuların büyümesi, gelişmesi ve onarımı için hayat boyunca devamlı olarak hayvana sağlanması gerekmektedir. Organizmanın yaşamsal faaliyetlerinin devamı için gerekli olduğu kadar et, süt, yumurta, tüy veya yapağ 1 oluşumu için de gereklidir. Proteinlerin hayvan beslemede önemi, onun hayvan organizmasındaki fonksiyonları ile yakından ilgilidir.

Protein içerikleri yönüyle yerel çeşitler incelendiğinde; en yüksek protein içeriği \%14.8 ile IG 128180 numaralı çeşitte, en düşük protein içeriği \%9.6 ile IG 128081 numaralı çeşitte belirlenmiştir. Akhisar-98 (\%12.5) protein içeriği ile yerel arpa çeşitlerine yakın protein içeriğine sahip olurken, Bülbül-89 çeşidi ise (\%14.2) yerel arpa çeşitlerinin çoğuna göre daha yüksek düzeyde protein içeriğine sahip olmuştur (Çizelge 7). Altuntaş (2012) Tokak yerel arpa çeşidi içinden seçilen saf hatların protein içeriklerinin \%12.00-14.47 arasında, Koçak ve ark. (1992) bazı arpa çeşitlerinin matlık kalitesi üzerine yürüttükleri çalışmada çeşitlerin protein oranının \%11.6-13.8 arasında, Öztürk ve ark. (2001) iki sıralı arpalarda ham protein oranının \%11.4-13.2 arasında, Çölkesen ve ark. (2002) 25 adet arpa çeşidinin protein oranının \%10.32-11.95 arasında değiştiğini ifade etmişlerdir.

Kün ve Akbay (1983) protein oranının yemlik arpalarda \%12-16, biralık arpada ise \%8-12 değerleri arasında olması gerektiğini bildirmişlerdir. Yerel arpa çeşitleri bu açıdan değerlendirildiğinde IG 18842, IG 28579, IG 28582, IG 28588, IG 28596, IG 128080, IG 128081, IG 128113, IG 128120, IG 128135, IG 128166 ve IG 128192 numaralı çeşitlerin protein içeriğinin \%12'den az olduğu ve bu çeşitlerin maltlık kalitede protein içerdiği gözlemlenmiştir. Hayvan yemi olarak kullanılan arpaların protein oranının \%12-16 arasında olmas1 istenmektedir. Yerel arpa çeşitleri bu açıdan değerlendirildiğinde IG 18801, IG 19110, IG 128078, IG 128083, IG 128116, IG 128136 ve IG 128180 numaralı çeşitlerin protein içeriğinin yüksek olduğu ve hayvan beslemede kullanılabileceği düşünülmüştür.

Çizelge 6. Dane örneklerinin mikro besin element içerikleri.

Table 6. Micronutrient element contents of grain samples.

\begin{tabular}{|c|c|c|c|c|c|}
\hline Sira No & Çeşitler & Demir (ppm) & Mangan (ppm) & Çinko (ppm) & Bakır (ppm) \\
\hline 1 & Bülbül 89 & $26.4 \mathrm{I}-\mathrm{J}$ & 14.0 B-C & $33.5 \mathrm{C}$ & 3.7 A-E \\
\hline 2 & Akhisar98 & 59.3 A-E & 17.4 A-C & 26.3 E-I & 4.0 A-D \\
\hline 3 & IG 128075 & 43.6 C-J & 17.0 A-C & $23.5 \mathrm{H}-\mathrm{M}$ & $3.3 \mathrm{~A}-\mathrm{F}$ \\
\hline 4 & IG 128111 & $63.8 \mathrm{~A}-\mathrm{C}$ & 20.4 A-B & 27.3 D-H & $4.4 \mathrm{~A}$ \\
\hline 5 & IG 128113 & 50.4 B-H & 14.7 B-C & 24.4 F-K & 3.6 A-E \\
\hline 6 & IG 128116 & $50.3 \mathrm{~B}-\mathrm{H}$ & $13.0 \mathrm{C}$ & 26.1 E-I & $2.8 \mathrm{C}-\mathrm{F}$ \\
\hline 7 & IG 128120 & 65.7 A-B & $22.1 \mathrm{~A}$ & 29.3 D-E & $3.4 \mathrm{~A}-\mathrm{F}$ \\
\hline 8 & IG 128134 & 31.9 H-J & $17.5 \mathrm{~A}-\mathrm{C}$ & $27.8 \mathrm{D}-\mathrm{G}$ & $3.8 \mathrm{~A}-\mathrm{E}$ \\
\hline 9 & IG 128135 & $48.9 \mathrm{~B}-\mathrm{H}$ & $15.9 \mathrm{~A}-\mathrm{C}$ & $16.9 \mathrm{O}$ & 3.7 A-E \\
\hline 10 & IG 128136 & $27.4 \mathrm{I}-\mathrm{J}$ & $16.7 \mathrm{~A}-\mathrm{C}$ & $24.0 \mathrm{G}-\mathrm{L}$ & 4.2 A-B \\
\hline 11 & IG 128190 & 37.2 F-J & $16.5 \mathrm{~A}-\mathrm{C}$ & $20.0 \mathrm{M}-\mathrm{O}$ & $3.8 \mathrm{~A}-\mathrm{E}$ \\
\hline 12 & IG 18801 & 41,1 D-J & $16.2 \mathrm{~A}-\mathrm{C}$ & $26.3 \mathrm{E}-\mathrm{I}$ & 3.6 A-E \\
\hline 13 & IG 18842 & 53.7 A-G & $12.0 \mathrm{C}$ & $31.1 \mathrm{C}-\mathrm{D}$ & 2.7 C-F \\
\hline 14 & IG 19097 & $26.3 \mathrm{I}-\mathrm{J}$ & 13.3 B-C & 25.8 E-J & $2.2 \mathrm{~F}$ \\
\hline 15 & IG 19110 & $56.3 \mathrm{~A}-\mathrm{F}$ & 13.3 B-C & $37.5 \mathrm{~B}$ & $3.2 \mathrm{~A}-\mathrm{F}$ \\
\hline 16 & IG 28579 & 40.0 E-J & $14.8 \mathrm{~B}-\mathrm{C}$ & 28.6 D-E & $3.1 \mathrm{~A}-\mathrm{F}$ \\
\hline 17 & IG 28582 & $62.5 \mathrm{~A}-\mathrm{D}$ & $14.8 \mathrm{~B}-\mathrm{C}$ & $22.0 \mathrm{~J}-\mathrm{M}$ & $3.0 \mathrm{~B}-\mathrm{F}$ \\
\hline 18 & IG 28588 & $50.4 \mathrm{~B}-\mathrm{H}$ & $12.7 \mathrm{C}$ & $23.0 \mathrm{I}-\mathrm{M}$ & $3.2 \mathrm{~A}-\mathrm{F}$ \\
\hline 19 & IG 28596 & 42.0 D-J & $14.8 \mathrm{~B}-\mathrm{C}$ & 20.4 L-O & $3.4 \mathrm{~A}-\mathrm{F}$ \\
\hline 20 & IG 28715 & $75.1 \mathrm{~A}$ & 13.5 B-C & 31.2 C-D & $3.2 \mathrm{~A}-\mathrm{F}$ \\
\hline 21 & IG 128078 & 41.2 D-J & $16.1 \mathrm{~A}-\mathrm{C}$ & $43.3 \mathrm{~A}$ & 4.0 A-D \\
\hline 22 & IG 128079 & $68.1 \mathrm{~A}-\mathrm{B}$ & $18.7 \mathrm{~A}-\mathrm{C}$ & $38.7 \mathrm{~B}$ & $4.4 \mathrm{~A}$ \\
\hline 23 & IG 128080 & 39.6 E-J & 14.6 B-C & $28.1 \mathrm{D}-\mathrm{F}$ & $3.3 \mathrm{~A}-\mathrm{F}$ \\
\hline 24 & IG 128081 & $52.2 \mathrm{~B}-\mathrm{H}$ & $17.1 \mathrm{~A}-\mathrm{C}$ & $28.2 \mathrm{D}-\mathrm{F}$ & $4.0 \mathrm{~A}-\mathrm{C}$ \\
\hline 25 & IG 128083 & 34.8 G-J & 13.3 B-C & 29.0 D-E & 3.6 A-E \\
\hline 26 & IG 128166 & 46.8 B-I & 14.2 B-C & $17.6 \mathrm{~N}-\mathrm{O}$ & 2.7 E-F \\
\hline 27 & IG 128180 & $22.7 \mathrm{~J}$ & $15.9 \mathrm{~A}-\mathrm{C}$ & $21.9 \mathrm{~J}-\mathrm{M}$ & $2.7 \mathrm{D}-\mathrm{F}$ \\
\hline 28 & IG 128192 & 36.9 F-J & $16.0 \mathrm{~A}-\mathrm{C}$ & $21.2 \mathrm{~K}-\mathrm{N}$ & $3.7 \mathrm{~A}-\mathrm{E}$ \\
\hline
\end{tabular}

Değerler 3 tekerrür ortalamasıdır. Aynı harflerle gösterilmeyen değerler arasındaki farklar \%5 düzeyinde önemlidir. 1-2 Sıra numaralı çeşitler tescilli çeşitleri göstermektedir. 3-11 Sıra numaralı çeşitler Akdeniz Bölgesi'ne ait yerel arpa çeşitlerini göstermektedir. 12-28 Sıra numaralı çeşitler Ege Bölgesi'ne ait yerel arpa çeşitlerini göstermektedir. 
Çizelge 7. Dane örneklerinin protein içerikleri (\%).

Table 7. Protein contents of grain samples (\%).

\begin{tabular}{|c|c|c|c|c|c|}
\hline Sira No & Çeşitler & Protein \% & Sira No & Çeşitler & Protein \% \\
\hline 1 & Bülbül 89 & $14.2 \mathrm{~A}-\mathrm{C}$ & 15 & IG 19110 & $14.5 \mathrm{~A}-\mathrm{B}$ \\
\hline 2 & Akhisar98 & $12.5 \mathrm{~F}-\mathrm{I}$ & 16 & IG 28579 & $11.5 \mathrm{~J}-\mathrm{M}$ \\
\hline 3 & IG 128075 & 12.3 G-J & 17 & IG 28582 & $11.3 \mathrm{~K}-\mathrm{N}$ \\
\hline 4 & IG 128111 & 12.3 G-J & 18 & IG 28588 & $11.1 \mathrm{~L}-\mathrm{N}$ \\
\hline 5 & IG 128113 & $11.9 \mathrm{I}-\mathrm{L}$ & 19 & IG 28596 & $12.0 \mathrm{H}-\mathrm{L}$ \\
\hline 6 & IG 128116 & 13.7 B-E & 20 & IG 28715 & $12.8 \mathrm{E}-\mathrm{H}$ \\
\hline 7 & IG 128120 & $10.6 \mathrm{~N}$ & 21 & IG 128078 & 14.1 A-D \\
\hline 8 & IG 128134 & 13.3 C-F & 22 & IG 128079 & 12.5 F-I \\
\hline 9 & IG 128135 & $10.6 \mathrm{M}-\mathrm{N}$ & 23 & IG 128080 & $11.2 \mathrm{~K}-\mathrm{N}$ \\
\hline 10 & IG 128136 & 14.1 A-D & 24 & IG 128081 & $9.6 \mathrm{O}$ \\
\hline 11 & IG 128190 & 12.3 G-J & 25 & IG 128083 & 13.3 D-F \\
\hline 12 & IG 18801 & 13.0 E-G & 26 & IG 128166 & $10.5 \mathrm{~N}$ \\
\hline 13 & IG 18842 & $12.0 \mathrm{H}-\mathrm{K}$ & 27 & IG 128180 & $14.8 \mathrm{~A}$ \\
\hline 14 & IG 19097 & $12.3 \mathrm{G}-\mathrm{J}$ & 28 & IG 128192 & $11.7 \mathrm{I}-\mathrm{L}$ \\
\hline
\end{tabular}

Değerler 3 tekerrür ortalamasıdır. Aynı harflerle gösterilmeyen değerler arasındaki farklar \%5 düzeyinde önemlidir.1-2 Sıra numaralı çeşitler tescilli çeşitleri göstermektedir. 3-11 Sıra numaralı çeşitler Akdeniz Bölgesi'ne ait yerel arpa çeşitlerini göstermektedir. 12-28 Sıra numaralı çeşitler Ege Bölgesi’ne ait yerel arpa çeşitlerini göstermektedir.

\section{Sonuç}

Akdeniz ve Ege Bölgelerine ait 26 adet yerel arpa çeşidi ile 2 adet tescilli arpa çeşidinin; makro-mikro bitki besin elementleri içerikleri ile protein oranlarının belirlenmesi ve arpa çeşitleri arasındaki farklılıkları ortaya koymak amacıyla çiftçi uygulamaları dikkate alınarak yürütülen bir yıllık çalışma sonucunda;

1. Çeşitlerin toplam $\mathrm{N}$ içeriklerinin ve dolayısıyla protein içeriklerinin iyi düzeyde olduğu belirlenmiştir.

2. Denemenin yürütüldüğü alanın yüksek Ca içeriğine sahip olmasından dolayı çeşitlerin hem yaprak hem de dane örneklerinin kalsiyumca yüksek grupta yer almasına neden olduğu düşünülmektedir.

3. Türkiye topraklarının $\mathrm{Zn}$ içeriğinin genel itibariyle düşük olması ve ayrıca çinkolu gübreleme yapılmaması çeşitlerin hem yaprak hem de dane örneklerinin çinko içeriğinin düşük olmasına neden olmuş olabilir.

4. Türkiye'ye özgü yerel arpa çeşitlerinin yaprak ve danelerinin incelenen parametreler bakımından genel itibariyle zengin olduğu buna karşılık daha sağlıklı sonuçların elde edilmesi için gübre dozlarının da ayarlandığı detaylı bir çalışmanın yeniden yürütülmesinin daha net sonuçlar doğuracağı kanaati uyanmıştır.

5. Özellikle Türkiye orijinli olan arpa köy çeşitlerinin çalışmalara konu olması yerli çeşitlerin üzerinde çalışmalar yapılmasını ve yerli kaynakların değerlendirilmesini bir kez daha dikkat çekmektedir.

\section{Kaynaklar}

Açıkgöz E, Hatipoğlu R, Altınok S, Sancak C, Tan A, Uraz D (2005) Yem bitkileri üretimi ve sorunları. Türkiye Ziraat Mühendisliği VI. Teknik Kongresi, Ankara, s. 503-518.

Alkan FR, Kandemir N (2015) Tokak yerel arpa çeşidi içinden seçilen safhatların bazı gıda, yem ve tarımsal özellikler bakımından varyasyonları. Tarla Bitkileri Merkez Araştırma Enstitüsü Dergisi 24: $124-139$

Altuntaş FR (2012) Tokak yerel arpa çeşidi içinden seçilen safhatların bazı gıda, yem ve tarımsal özellikler bakımından varyasyonları.
Yüksek Lisans Tezi, Gaziosmanpaşa Üniversitesi Fen Bilimleri Enstitüsü, Tokat.

Black CA (1965) Methods of soil analysis Part 2, American Society of Agronomy Inc Publisher Madisson, Wilconsin, U.S.A. 1372-1376.

Bouyoucos GJ (1955) A recalibration of the hydrometer method for making mechanicalan alysis o fthe soils. Agronomy Journal, 43: 434-438.

Byrne I, Rasmusson DC(1974) Recurrent selection for mineral content in wheat and barley. Euphytica 23: 241-249.

Carr PM, Horsley RD, Poland WW (2004) Barley, Oat, andCerealPeaMixtures as Dry land Forages in the Northern Great Plains. AgronomyJournal 96: 677-684.

Chapmann ND, Pratt PF, Parker F (1961) Methods of analysis for soils, plant sandwaters. University of California Division of Agricultural Sciences, Riverside.

Çağlar KÖ (1949) Toprak Bilgisi. Ankara Üniversitesi Ziraat Fakültesi Yayınları Sayı: 10.

Çölkesen M, Öktem A, Engin A, Öktem AG (2002) Bazı arpa çeşitlerinin (Hordeum vulgare L.) Kahramanmaraş ve Şanlıurfa koşullarında tarımsal ve kalite özelliklerinin belirlenmesi. Kahramanmaraş Sütçü İmam Üniversitesi Mühendislik Bilimleri Dergisi 5: 76-87.

Elçi Ş (2005) Baklagil ve buğdaygil yem bitkileri. T.C. Tarım ve Köy İşleri Bakanlığı Yayınları. ISBN 975-407-189-6, Ankara, s. 486.

Jackson ML (1967) Soil chemicalanalysis. Prentice Hall of India Private Limited, New Delhi.

Jones JR JB, Wolf B, Mills HA (1991) Plant Analysis Handbook. A Practical Sampling, Preparation, Analysis, and Interpretation Guide. Micro-Macro Publishing Inc. Athens, Georgia, USA.

Kacar B, İnal A (2008) Bitki analizleri. Nobel Yayınları. Yayın no: 1241(63).

Kandemir N, Tüzen M, Sarı H, Mendil D (2005) An increase of the mineral content of barley grain by genotype, planting time and seed size. Asian Journal of Chemistry 17: 481-489.

Kandemir N (2004) Tokat-Kazova şartlarına uygun maltlık arpa çeşitlerinin belirlenmesi. Gaziosmanpaşa Üniversitesi Ziraat Fakültesi Dergisi 21: 94-100.

Koçak N, Karababa E, Özkara R (1992) Bazı arpa çeşitlerinin maltlık kalitesi üzerine araştırmalar. Arpa-malt semineri, Konya. 
Kün E, Akbay G (1983) Altı sıralı arpaların maltlık kriterleri yönünden incelenmesi. TÜBİTAK 7. Bilim Kong. Bildirileri, Ankara.

Lindsay WL, Norvell WA (1978) Development of a DTPA soil test for Zinc, Iron, Manganese and Copper. Soil Science Society of America Journal 42: 421-428.

Olsen SR, Sommers EL (1982) Phosporus soluble in sodium bicarbonate, Methods of Soil Analysis, Part 2, Chemical and Microbiological Properties. Edit: A.L. Page, P.H. Miller, D.R. Keeney, pp. 404-430.

Öztürk A, Çağlar Ö, Tufan A (2001) Bazı arpa çeşitlerinin Erzurum koşullarına adaptasyonu. Atatürk Üniversitesi Ziraat Fakültesi Dergisi 32: 109-115.
Plank CO, Donohue SJ (2000) Reference sufficiency ranges for plantanalysis in the Southern Region of United States. Raleigh, US.

Villacres E, Rivadeneira M (2005) Barley in Ecuador: production, grain quality for consumption and perspectives for improvement. Pages 127-137 in: FoodBarley-Importance Uses and Local Knowledge: Proc. International Workshop on Food Barley Improvement, Jan. 2002. S. Grandoand H. G. Macpherson, eds. ICARDA, Aleppo, Syria. 